\title{
Morphological, genetic and clinical correlations in infantile hemangiomas and their mimics
}

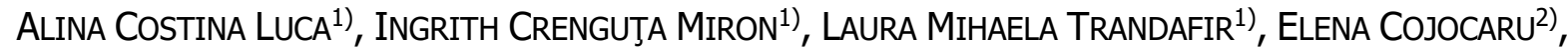

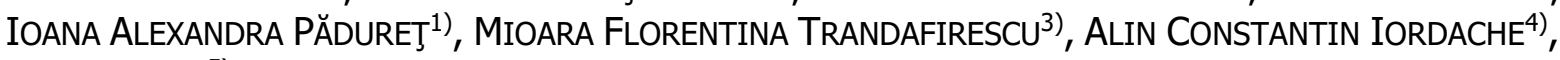 \\ ELENA TARCĂ ${ }^{5)}$
}

\author{
1) Department of Mother and Child Medicine - Pediatrics, Grigore T. Popa University of Medicine and Pharmacy, Iaşi, Romania \\ 2) Department of Morphofunctional Sciences I - Pathology, Grigore T. Popa University of Medicine and Pharmacy, Iaşi, Romania \\ 3) Department of Morphofunctional Sciences I - Histology, Grigore T. Popa University of Medicine and Pharmacy, Iaşi, Romania \\ ${ }^{4)}$ Second Surgery Department - Neurosurgery, Grigore T. Popa University of Medicine and Pharmacy, Iaşi, Romania \\ ${ }^{5)}$ Second Surgery Department - Pediatric Surgery, Grigore T. Popa University of Medicine and Pharmacy, Iaşi, Romania
}

\begin{abstract}
Infantile hemangiomas $(\mathrm{IHs})$ are the most frequent pediatric benign vascular tumors, with a reported incidence of $5 \%$ to $10 \%$. They have self-limiting evolution pattern divided into a growth phase in the first 12 months and a regression one, that may take up to 10 years. Occasionally, hemangiomas might lead to local or systemic complications, depending on their morphological characteristics. The first line of treatment is $\beta$-blockers, such as Propranolol, Timolol, Nadolol, administered either locally or systemically. Newer therapeutic strategies involving laser therapy and angiotensin-converting enzyme inhibitors are being studied, while older treatment modalities like corticosteroids, Imiquimod, Vincristine, Bleomycin and Interferon- $\alpha$ have become second line therapy options. Before establishing the appropriate treatment, clinical, histological, and imaging investigations are required.
\end{abstract}

Keywords: infantile hemangioma, histopathology, genetics, management, differential diagnosis.

\section{Introduction}

Infantile hemangioma $(\mathrm{IH})$ is the most common vascular tumor of the child, with an incidence of $5-10 \%$ at the end of the first year of life [1]. Increased risk of developing the tumor is related to premature birth, low birth weight, female gender, and Caucasian race [2, 3] and also multiple gestations, increased maternal age, in vitro fertilization, pre-eclampsia and placental anomalies [4]. According to the new classification of vascular diseases, IHs are benign tumors and represent a distinct group from vascular malformations. Depending on their depth, IHs can be superficial, mixed or deep. If only the superficial dermis is affected, the color is typically bright red, whereas deeper IHs have a blue hint $[5,6]$. Morphologically, IHs can be localized or segmental or exhibit an indeterminate phenotype $[6,7]$.

\section{a Histopathological features of IHs}

From a pathogenic point of view, angiogenesis (formation of new vessels from pre-existing vessels) and vasculogenesis (de novo formation of blood vessels) participate in the process of neovascularization in hemangioma [7]. Among the cells participating in the formation of new vessels, pericytes, endothelial cells (ECs), stem/progenitor cells were studied [8,9]. IHs have a twostage rhythm of development, with a proliferative phase in the first year of life, more intense during the first three months, followed by the involution phase $[7,10]$.
During the proliferative phase, blood vessels are disorganized and composed of immature non-permeable ECs, possibly due to alpha-smooth muscle actin ( $\alpha$-SMA). In the involution phase of the tumor, the blood vessels mature and grow in size, but are reduced in number. The vascular tissue is replaced with fat, connective tissue, and fibroblasts [9].

As is the case with any cell, energy metabolism is a very important part of cells comprising IHs. In a normal cell, energy is obtained by mitochondrial oxidative phosphorylation under aerobic conditions. Aerobic glycolysis or the Warburg effect is another way of obtaining energy, one found in cancer cells and also in those forming hemangiomas. Investigations on glycolysis metabolism in hemangioma-derived endothelial cells (HemECs) unveiled that glucose consumption and adenosine triphosphate (ATP) production were higher in HemECs, while lactate production was lower. Also, hypoxia did not significantly alter glycolytic metabolism in these cells. Levels of glucose transporter 1 (GLUT1), human kallikrein 2 (hK2), 6-phosphofructo-2-kinase 3 (PFKFB3), lactate dehydrogenase A (LDHA) and hypoxia-inducible factor 1-alpha (HIF-1 $\alpha$ ) were higher in HemEcs that in normal ECs in normoxic environment; under hypoxia, hK2, PFKFB3, pyruvate kinase M2 (PKM2), HIF-1 $\alpha$ were higher than in normal cells. All the above-mentioned proteins are extremely important molecules for glycolysis, with a crucial role in proliferative activities, angiogenesis, and migration capacity in HemECs [9, 11, 12].

This is an open-access article distributed under the terms of a Creative Commons Attribution-NonCommercial-ShareAlike 4.0 International Public License, which permits unrestricted use, adaptation, distribution and reproduction in any medium, non-commercially, provided the new creations are licensed under identical terms as the original work and the original work is properly cited. 
GLUT1 positive is a name tag for IHs and its inhibition causes a decrease in angiogenesis and migration of hemangioma-derived cells. Genetic silencing of PFKFB3 reduced angiogenesis. Inhibition of $\mathrm{hK} 2$ had a negative impact on proliferation, angiogenesis, and migration [12]. It is self-explanatory why targeting glucose metabolism may be an attractive therapeutic strategy for treating hemangiomas.

From a histological point of view (Figures 1-8), hemangiomas in their proliferative phase present lobules with a high density of capillaries-like vessels, displaying plumped ECs, a thin basal layer surrounded by a layer of pericytes $[13,14,15]$. Immunohistochemical markers used to identify hemangioma cells are GLUT1, cluster of differentiation (CD) 31, CD34, $\alpha$-SMA, $\operatorname{Ki} 67[15,16]$.

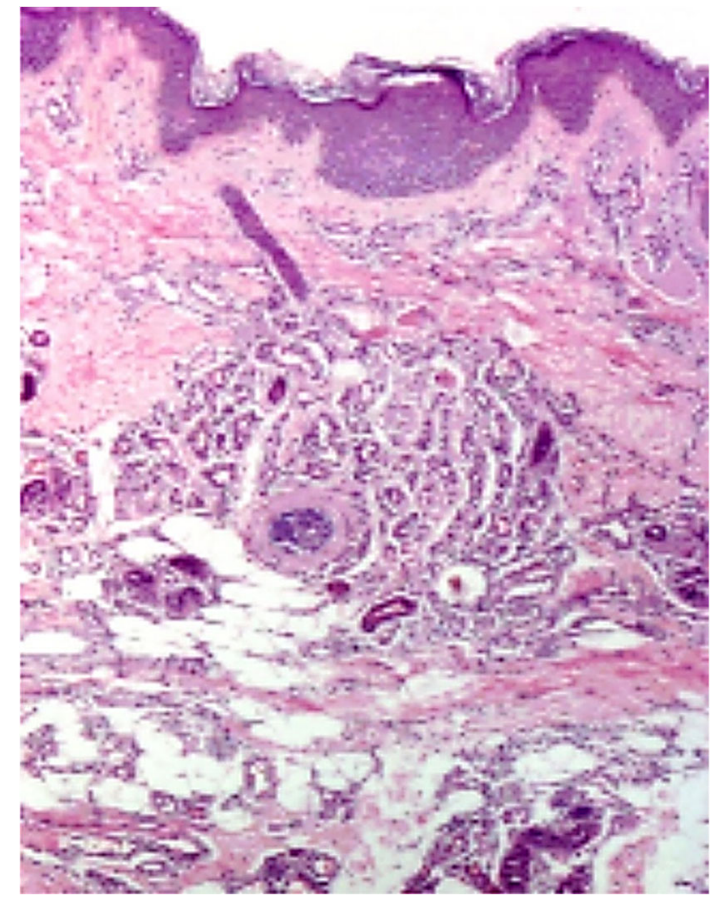

Figure 1 - Hemangioma: general view [HematoxylinEosin (HE) staining, $\times 40]$.

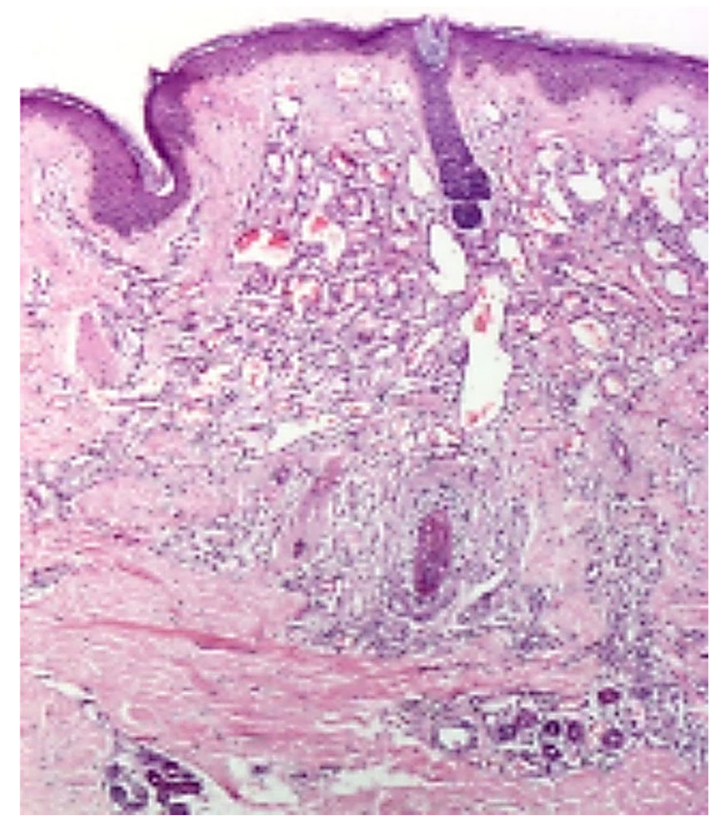

Figure 2 - Vascular lobules below normal epithelium (HE staining, $\times 40)$.

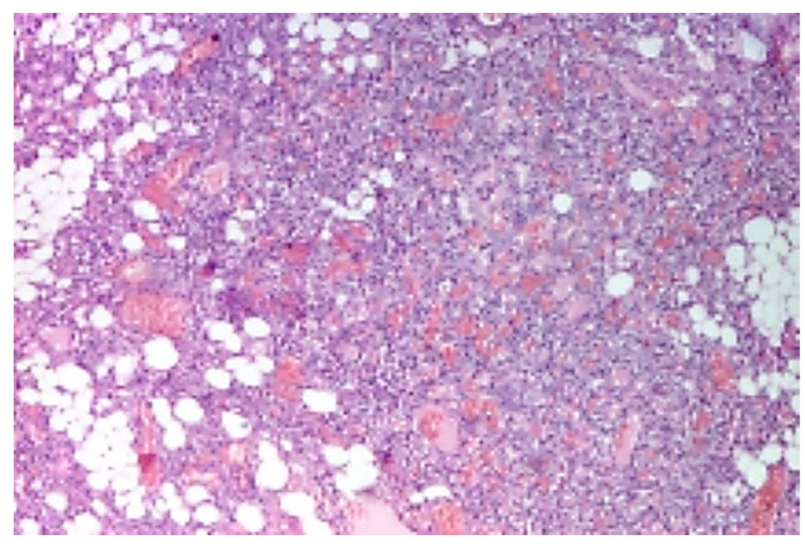

Figure 3 -Dermis with vascular proliferation showing plump endothelial cells (HE staining, $\times 40)$.

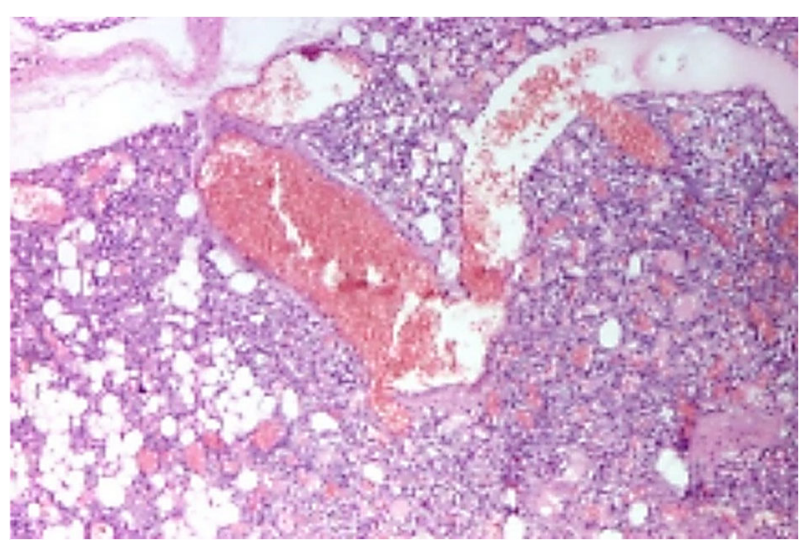

Figure 4 - Vascular spaces lined by a single layer of bland endothelial cells (HE staining, $\times 40)$.

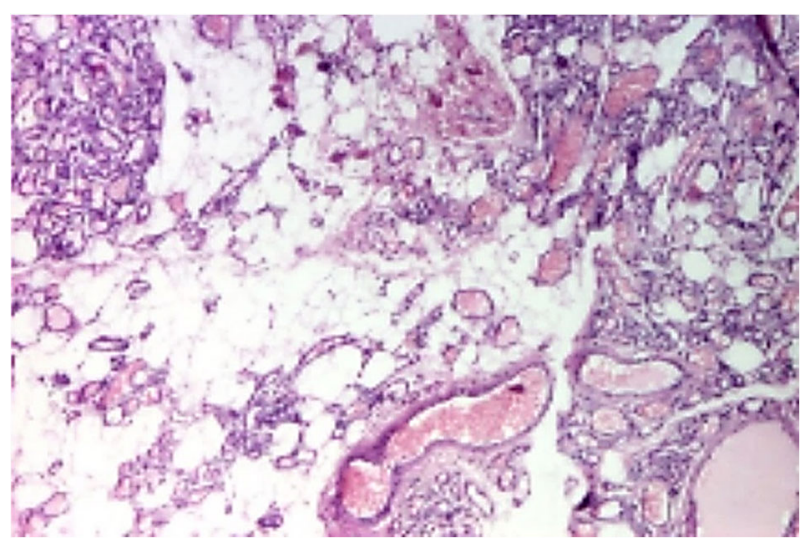

Figure 5 - Dilated vascular channels having red blood cells and lined by flat endothelial cells (HE staining, $\times 40$ ).

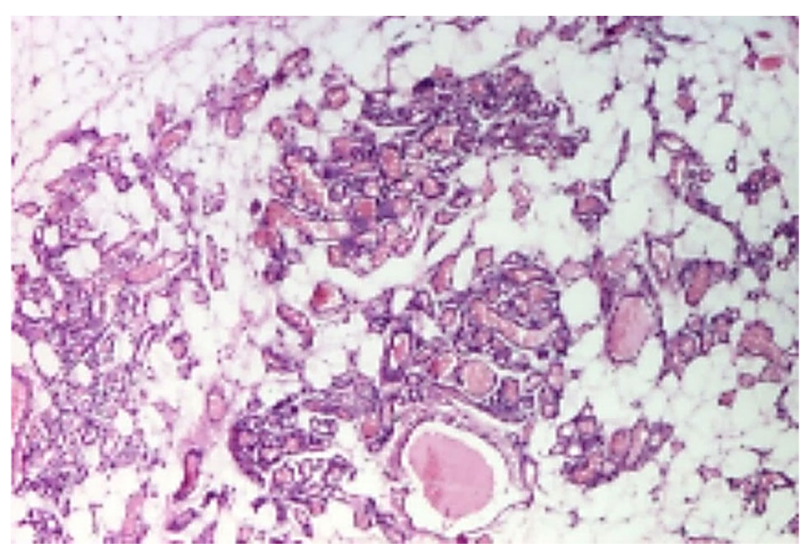

Figure 6 - Vascular channels into the deep dermis and hypodermis (HE staining, $\times 40)$. 


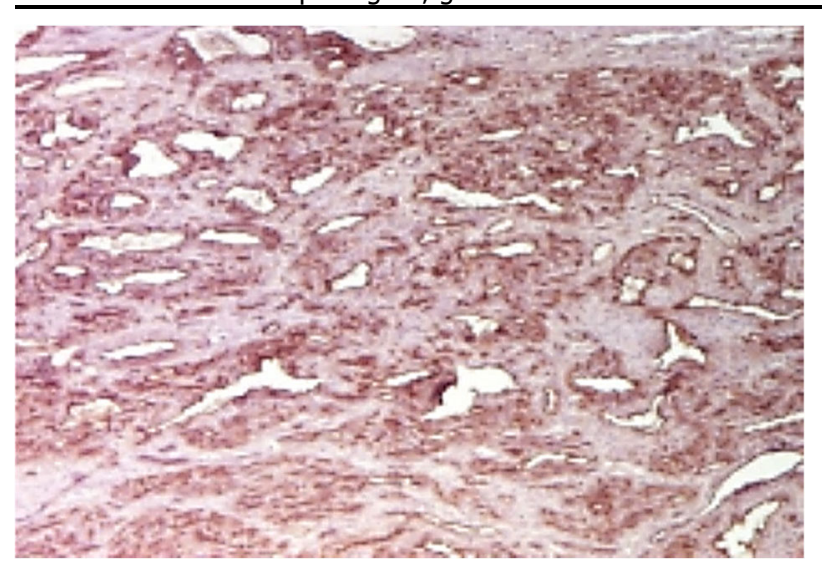

Figure 7 - Endothelial cells positive for anti-CD34 antibody (Anti-CD34 antibody immunostaining, $\times 40$ ). CD34: Cluster of differentiation 34.

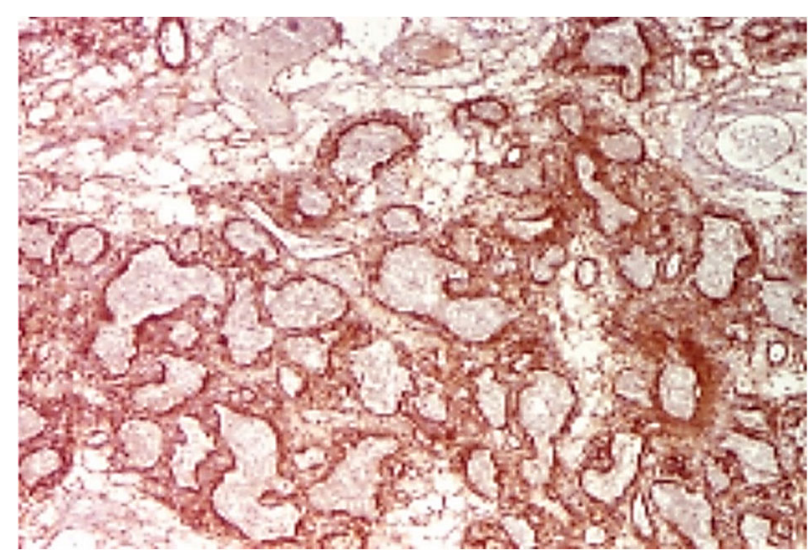

Figure 8 - Vascular channels positive for anti- $\alpha-S M A$ antibody (Anti- $\alpha-S M A$ antibody immunostaining, $\times 40)$. a-SMA: Alpha-smooth muscle actin.

\section{$\neg$ Genetic identity of IHs before and after treatment}

The mutational blueprint has also been investigated via next-generation sequencing and mutations in the mitogen-activated protein kinase (MAPK) pathway have been linked to lobular capillary hemangioma [2, 7]. However, most studies concur on the fact that the origin of IH is multifactorial and when a hereditary component is incriminated, the transmission is autosomal dominant, with a number of studies also suggesting maternal transmission [2, 17].

Putative biomarkers for proliferative and involution stages of IH, as well as for the Propranolol activity measurement have been investigated. Gomez-Acevedo et $a l$. analyzed IHs transcriptome and the changes that occur during the proliferation and involution phases of the hemangioma, as well as changes that are caused by Propranolol treatment. They concluded that aldehyde dehydrogenase 1A1 (ALDH1A1), endothelial PAS domain protein 1 (EPAS1), LIM and SH3 domain protein 1 (LASP1), solute carrier family 25 member 23 (SLC25A23), and myosin-binding protein 1 (MYOB1) genes are regulated by changes in the transcriptome owed to Propranolol treatment $[16,18]$.

The main actions of the $\beta$-blocker are related to matrix metalloproteinases (MMPs) expression, hypoxia, vasoconstriction, and apoptosis [19]. Through its antagonistic role on the receptors from the ECs, Propranolol inhibits cyclic adenosine monophosphate (cAMP) formation and thus decreases protein kinase A (PKA) and nitric oxide (NO) levels [18]. By the same mechanism, Propranolol reduces MAPK signaling. EPAS1 gene expression is enhanced during hypoxia periods and it encodes HIF- $2 \alpha$, which in turn acts upon ECs by means of vascular endothelial growth factor (VEGF), erythropoietin (EPO) and GLUT1. The action of HIF- $2 \alpha$ however is inhibited by Propranolol's effect on the PKA and MAPK signaling [9, 18].

Downregulation of LASPI gene occurs during the involution phase as confirmed by reverse transcription polymerase chain reaction (RT-PCR) testing and this is the mechanism by which Propranolol inhibits MMPs formation. Independent of Propranolol treatment, there are a series of proliferation biomarkers that present a linear response. Angiopoietin 2 (ANGPT2) gene, encoding angiopoietin 2, and secreted by the Palade bodies in the vascular endothelium, is increased under hypoxic conditions and, in the presence of VEGF, facilitates angiogenesis $[16,18]$.

Collagen type IV alpha 2 chain (COL4A2) gene, encoding for collagen IV, has a decreased expression during the involution phase of the hemangioma. Integrin subunit alpha 1 (ITGAl) gene encodes for integrin $\alpha_{1} \beta_{1}$ that in turn interacts with collagen IV during the proliferation stage of $\mathrm{IH}$, only to be downregulated in the involution phase $[18,20]$.

Platelet-derived growth factor receptor-beta $(P D G F R B)$, ribonucleic acid (RNA) binding Fox-1 homolog 2 (RBFOX2), matrix-remodeling-associated protein 5 (MXRA5), vasohibin $1(V A S H 1)$, peroxidasin $(P X D N)$, and $C O L 4 A 2$ genes expression also attenuates in time, making them valuable markers for disease progression. $R B F O X 2$ gene is a member of the Rbfox-splicing factors, and it is responsible for the alternative splicing in vascular CaV1.2 channels, which have a regulatory role for intramural pressure change because of blood flow fluctuations [21]. It has been suggested that $R B F O X 2$ could be used as a biomarker, along with Doppler ultrasound in order to establish IH development sites based on expression levels and flow velocities [18, 22, 23].

On the other hand, ATPase $\mathrm{Na}^{+} / \mathrm{K}^{+}$transporting subunit beta 1 (ATP1B1), CD9, fibulin 1 (FBLN1), N-Myc downstream regulated $1(N D R G 1)$ and secreted frizzled related protein 1 (SRFP1) genes have an elevated expression during the involution phase of the hemangioma. ATP1B1 gene encodes for a $\beta_{1}$ subunit of a $\mathrm{Na}^{+} / \mathrm{K}^{+}$-ATPase, with a significant role in cell interaction and adhesion. The lowering level of ATP1B1 during the initial proliferation phase suggests that IH might exhibit cancer-like mechanisms of development [18, 21].

As effective biomarkers should come from a readily attainable source, studies regarding the levels of microRNA (miRNA) and the changes that occur during different hemangioma development stages and, of course, the influence that Propranolol has on these small molecules have been made [24]. Biswas et al. identified increased urinary levels of miRNA-126 in children with a proliferative hemangioma and managed to establish a proliferation window between six and nine months of age. Afterwards, the levels of miRNA-126 in urine dropped to values encountered in healthy age-matched controls [23]. 
The cluster of miRNA found on chromosome 19, named C19MC is highly expressed in children with IHs and may also help differentiate them not only from healthy subjects, but also from children suffering from other types of vascular tumors. Also, circulating levels of miR-517c-3, e.g., helped identify children with either proliferative or involuting tumor and the same miRNA molecule exhibited plasma levels linked to tumor size [25]. Tissue miRNA profiling may be a tool for the differential diagnosis between IHs and non-involuting congenital hemangioma, a tumor that does not respond to Propranolol treatment [24]. Even more, the chromosome 19 miRNA cluster proved to be an effective therapy control biomarker, since its levels decreased in Propranolol-treated and involuted cases, while other miRNAs levels were unaffected [23, 25].

Cell-free miRNAs are attractive disease biomarkers and some of them even novel therapeutic targets, because of their stability in different tissue samples under a variety of preservation techniques, wide availability and specific cell uptake and release [18, 24].

\section{Histopathological basis for differential diagnosis}

Hemangiomas have superposing clinical characteristics with other soft tissue tumors with high vascular density; therefore, a thorough differential diagnostic is required. Important criteria include ultrasonography (US), clinical and histological aspects of each type of tumor [26]. Different soft tissue lumps may mimic IH and their histological portrait acts as an important discriminator.

\section{Pyogenic granuloma}

Pyogenic granuloma represents a mucocutaneous lesion commonly found on lips, gingiva, mucosa, nose, fingers, and face. Clinically, there are red or bluish papules or polyps prone to bleeding. Trauma, medications, and hormonal imbalance act as chronic irritating factors that determine an aberrant response causing the granuloma; despite the name, it has no relation to any infection. Histopathologically, there are lobules of curved capillaries and venules lined by plump ECs, with fibrous stroma and inflammatory cell infiltration. CD34-positive immunostaining is an indicator of active proliferation of the vessels [27, 28, 29].

\section{Syringocystadenoma papilliferum}

Syringocystadenoma papilliferum is a skin hamartoma, arising mainly from the apocrine gland. Clinically, it appears either as an erythematous plaque, a linear group of nodules or as a single nodule. Histopathologically, extensive papillary growth of epithelial aggregates form invaginations into the dermis. The high columnar epithelium is connected to the epidermis. Immunostaining is positive for carcinoembryonic antigen, gross cystic disease fluid protein 15 (GCDFP-15, also called BRST2), Leu-M1 antigen (CD15), lysozyme. The treatment of choice is complete surgical excision; however, carbon dioxide laser can be useful for lesions not suitable for surgery $[13,30]$.

\section{Aneurysmal benign fibrous histiocytoma}

Aneurysmal benign fibrous histiocytoma represents a benign dermal tumor composed of fibrohistiocytic cells.
Histological studies show a mass diffusely positive for CD10 and focally for CD68, factor XIIIa, $\alpha$-SMA and consistently negative for cytokeratins, S100, desmin and CD34 [31, 32].

\section{Paronychia}

Paronychia involves the soft tissue fold around the fingernail, and it is caused by a bacterial infection of the paronychial tissue. Histological studies reveal diffuse, dense, uniform plasma cell infiltrate of the upper dermis. Chronic, untreated cases may lead to osteomyelitis [29, 33, 34].

\section{Cranial fasciitis}

Cranial fasciitis is a benign tumor of the skull, originating in the epicranial aponeurosis. It occurs almost exclusively in children younger than six years, although it has been reported also in children younger than one year. Local trauma may be a cause. Clinically, there is a unique rapidly growing, painless scalp tumor. Histopathologically, there are fibroblasts and myofibroblasts in a myxoid or hyalinized matrix. Also, osseous metaplasia may be present $[29,35]$.

\section{Metastatic neuroblastoma}

Metastatic neuroblastoma is the leading malignant tumor of neonates, arising from the developing sympathetic nervous system. Clinically, "blueberry muffin baby" appearance may be the initial presentation of metastatic neuroblastoma. Histopathologically, there are neuroblasts with salt and pepper nuclei interspersed with differentiating pre-ganglion cells, neuropil, rosettes and in some cases Schwannian stroma. Significant correlations between CD44 expression and tumor prognosis were proved, CD44+ tumors having a favorable outcome [29, 36].

\section{Extraskeletal Ewing sarcoma}

Extraskeletal Ewing sarcoma is part of a family of tumors that arise in bone or soft tissue. Extraskeletal Ewing sarcoma manifests in young patients as a large, rapidly growing, and unique, superficial, or deep soft tissue mass. Histologically, it is formed by a group of high-grade small round cell tumors with prominent nuclei and indistinct cell membranes. Also, pseudo-rosettes resulting from necrosis may be present. There is a positive immunostaining for CD99, Friend leukemia integration 1 (FLI1), and vimentin [29, 37].

\section{Plexiform fibrohistiocytic tumor}

Plexiform fibrohistiocytic tumor is more common in females and typically presents in children and young adults. Clinically, there is a soft tissue nodule or indurated plaque in the subcutaneous adipose tissue. Overlaying epidermis and dermis are usually normal. Histopathologically, there are plexiform or multinodular proliferation of fibrohistiocytic cells and osteoclast-like giant cells, as well as chronic inflammatory infiltrate and prominent dilated vessels. Immunostaining is positive for vimentin, CD68, $\alpha$-SMA and negative for S100, cytokeratin, CD45, factor VIII, desmin [29, 38]. 


\section{ㅁ Ultrasonographic criteria for differential diagnosis of IH}

Alongside clinical and histological evaluation of a soft tissue tumor, imaging techniques are an important source of diagnostic information required to properly classify and treat a vascular tumor. Although, magnetic resonance imaging (MRI) and computed tomography (CT)-based investigations gained a lot of attention [39, 40], US and Doppler analysis are still useful, cost-efficient, and readily available tools for any diagnostician in the quest to categorize and surveille most of the vascular malformations, including IHs and their mimics [39, 41]. During the proliferative phase, the US findings in $\mathrm{IH}$ are a heterogenic mass, with high density vascularization $\left(>5\right.$ vessels $\left./ \mathrm{cm}^{2}\right)$ with a high Doppler shift and low flow resistance [29]. In the involution phase, the vessel density decreases. However, there is no pathognomonic lesion for $\mathrm{IH}$, and careful analysis is required. US characteristics of the most frequent differential diagnosis for $\mathrm{IH}$ are summarized in Tables 1 and 2 for the benign and malignant tumors, respectively.

Table 1 - US characteristics of the frequent benign differential diagnosis

\begin{tabular}{|c|c|}
\hline Benign lesions & US characteristics \\
\hline $\begin{array}{l}\text { Pyogenic } \\
\text { granuloma }\end{array}$ & $\begin{array}{l}\text { - Ill-defined, oval; } \\
\text { - Hypoechoic, marked central and } \\
\text { peripheral vascularization with } \\
\text { feeders' vessels; or } \\
\text { - Decreased peripheral vascularity; } \\
\text { - Venous and arterial flow of low } \\
\text { resistive index. }\end{array}$ \\
\hline $\begin{array}{l}\text { Syringocystadenoma } \\
\text { papilliferum }\end{array}$ & $\begin{array}{l}\text { - US findings are similar to those of a } \\
\text { typical hemangioma. }\end{array}$ \\
\hline $\begin{array}{c}\text { Wart versus } \\
\text { eccrine poroma }\end{array}$ & $\begin{array}{l}\text { Wart: } \\
\text { - Fusiform; } \\
\text { - Hypoechoic focal increase in the } \\
\text { arterial dermal flow. } \\
\text { Eccrine poromas: } \\
\text { - Well-defined; } \\
\text { - Hypoechoic; } \\
\text { - Avid post-contrast enhancement on MRI. }\end{array}$ \\
\hline $\begin{array}{l}\text { Aneurysmal benign } \\
\text { fibrous histiocytoma }\end{array}$ & $\begin{array}{l}\text { - Well-defined, rounded; } \\
\text { - Mainly hypoechoic, posterior acoustic } \\
\text { enhancement; } \\
\text { - Significant arterial and venous flow. }\end{array}$ \\
\hline Paronychia & $\begin{array}{l}\text { - Diffuse, periungual thickening; } \\
\text { - Areas of increased echogenicity } \\
\text { interposed with hypoechoic areas. }\end{array}$ \\
\hline Cranial fasciitis & $\begin{array}{l}\text { - Small, superficial; } \\
\text { - Hypoechoic, marked internal vascularity; } \\
\text { - Venous and arterial low resistance } \\
\text { arterial flow. }\end{array}$ \\
\hline Hemangioma & $\begin{array}{l}\text { - Well-defined, ovoid; } \\
\text { - Hypoechoic, high vessel density; } \\
\text { - High Doppler shift; } \\
\text { - Low flow resistance. }\end{array}$ \\
\hline
\end{tabular}

MRI: Magnetic resonance imaging; US: Ultrasonography.
Table 2 - US characteristics of malignant tumors

\begin{tabular}{|c|c|}
\hline Malignant tumors & US characteristics \\
\hline $\begin{array}{c}\text { Metastatic } \\
\text { neuroblastoma }\end{array}$ & $\begin{array}{l}\text { - Blood flow consistent with localized } \\
\text { deep hemangiomas; } \\
\text { - Peak velocity between 10-20 m/s. }\end{array}$ \\
\hline $\begin{array}{c}\text { Extraskeletal Ewing } \\
\text { sarcoma }\end{array}$ & $\begin{array}{l}\text { - Hypoechoic; } \\
\text { - Increased Doppler flow; } \\
\text { - Marked internal vascularity. }\end{array}$ \\
\hline
\end{tabular}

US: Ultrasonography.

\section{$\square$ Current therapeutic strategies and monitoring of IH}

$\mathrm{IH}$ can be harmless, which is why conservative measures are recommended, but in rare cases when complications such as obstruction, bleeding, ulceration, or superinfection occur (Figures 9 and 10), therapeutic intervention is required [7, 14, 42]. Roughly for every $10 \mathrm{~cm}^{2}$ increase in lesion size, there is a $4 \%$ increase in the need for treatment, and 5\% increased chances for complication [42]. In the wake of the novel coronavirus disease 2019 (COVID-19) pandemic, the Hemangioma Investigator Group (HIG) released a classification of IH based on size and location useful in evaluating the probability for complications, establishing the optimum moment for initiating conservative treatment and directing the patient monitoring techniques [3] (Table 3).

\section{Figure 9-Obstructing hemangioma of the face.}
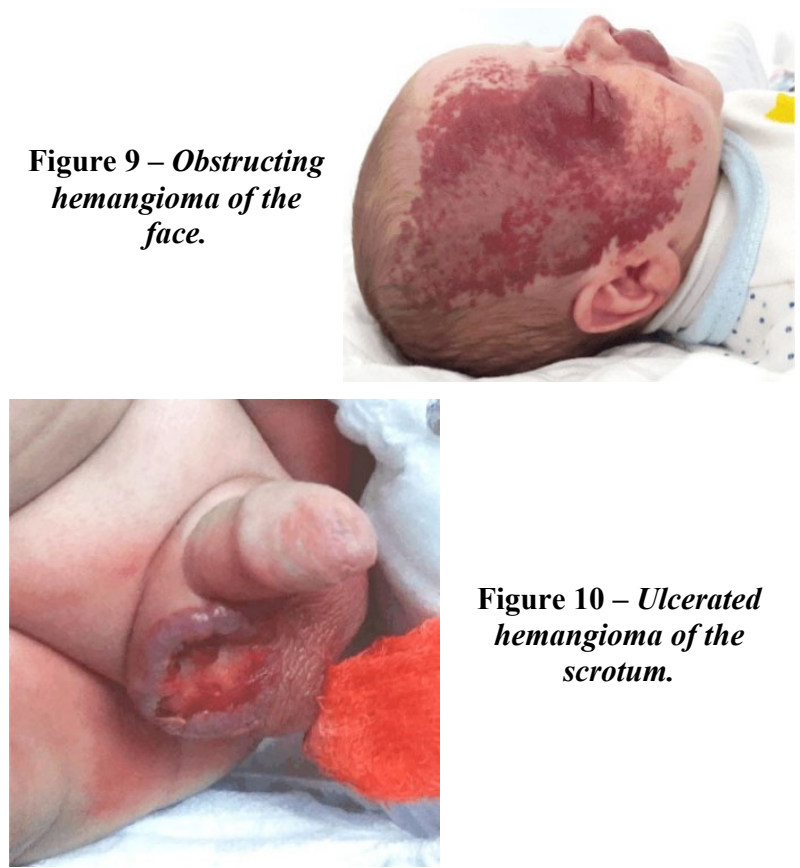

Figure 10 - Ulcerated hemangioma of the scrotum.

Based on the factors involved in the pathogenesis of $\mathrm{IH}$, over time various targeted therapies have been used: corticotherapy, interferon (IFN), sclerosing agents, $\beta$-blocker therapy and laser therapy.

Table 3 - Risk stratification depending on IH morphological characteristics, number of lesions, location [3]

\begin{tabular}{|c|c|c|c|}
\hline Highest & High & Medium & Low \\
\hline $\begin{array}{l}\text { - } 55 \text { cm or facial/scalp; } \\
\text { - Large or segmental } \\
\text { lumbosacral or perineal; } \\
\text { - Multifocal IHs ( } \geq 5 \text { ) and } \\
\text { abdominal hemangiomas } \\
\text { (US); } \\
\text { - Periocular IH with potential } \\
\text { impact on visual axis. }\end{array}$ & $\begin{array}{l}\text { - Large IH on trunk/extremities } \\
\text { - Facial IH } \geq 2 \mathrm{~cm}(>1 \mathrm{~cm} \text { if } \\
\leq 3 \text { months of age); } \\
\text { - Nasal tip or lip IH even if }<1 \mathrm{~cm} \text {; } \\
\text { - Oral; } \\
\text { - Neck or scalp IH }>2 \mathrm{~cm} \text { during } \\
\text { growth phase; } \\
\text { - Breast; } \\
\text { - Ulcerated hemangioma. }\end{array}$ & $\begin{array}{l}\text { - Localizes perineal IH without } \\
\text { ulceration; } \\
\text { - Trunk of extremity IH >2 cm } \\
\text { especially in growth phase or } \\
\text { if abrupt transition from normal } \\
\text { to affected skin. }\end{array}$ & $\begin{array}{l}\text { - } \mathrm{IH}<2 \mathrm{~cm} \text { on trunk of } \\
\text { extremities in areas easily } \\
\text { covered by clothing; } \\
\text { - IH on trunk of extremities } \\
>2 \mathrm{~cm} \text { if gradual transition } \\
\text { from normal to affected skin. }\end{array}$ \\
\hline
\end{tabular}

$\mathrm{IH}$ : Infantile hemangioma; US: Ultrasonography. 


\section{Corticosteroid therapy}

Corticosteroid (CS) therapy has been widely used in the treatment of IH. Systemic therapy using Prednisolon $2-3 \mathrm{mg} / \mathrm{kg} /$ day every morning had a $33 \%$ success rate, with only one third of lesions regressing, one-third remaining stable, and the last third showing no response $[26,39,43]$. Growth delay, skin hypopigmentation, hypertrichosis, Cushingoid appearance, behavior alteration, irritability, glaucoma, cataract are all complications associated with systemic administration of CSs [41, 43, 44]. Intralesional or topical regimes are used for small deep resistant IHs. Triamcinolone acetonide with doses from 10 to $40 \mathrm{mg} / \mathrm{mL}$, maximum $3 \mathrm{mg} / \mathrm{kg} /$ day has important side effects such as local skin atrophy, necrosis, calcification, and depigmentation $[26,41]$. Since hemangiomas have an important degree of vascularization, systemic absorption is increased even after topical treatment $[26,45]$.

\section{Imiquimod}

Imiquimod is another topical medication, which has a modulatory effect on the immune response. However, it is indicated as a third-line therapeutic agent $[43,46]$.

\section{IFN- $\alpha$}

IFN- $\alpha$ inhibits angiogenesis, but the risk for spastic diplegia and other complications has this therapy reserved for life-threatening hemangiomas [40, 47].

\section{Angiotensin-converting enzyme inhibitors}

Angiotensin-converting enzyme inhibitors (ACE) have been studied as potential therapeutic agents, with a small study comparing results from Propranolol with Captopril [48]. Studies have demonstrated a likely relationship between IH development and the reninangiotensin system (RAS) function, which prompted the investigation of ACE inhibitors, such as Captopril, as possible treatment alternatives. Overall, the $\beta$-blocker therapy showed better results, but further investigation is needed $[43,48]$. Because of multiple important side effects, including anemia, peripheral neuropathy or leukopenia, Vincristine considered once a second line therapy, following $\mathrm{CS}$, is now administered in the Kasabach-Merritt phenomenon (Kaposiform hemangioendothelioma and tufted angiomas) [7, 40, 42, 49].

\section{Bleomycin A5}

Therapy with Bleomycin A5 poses a risk for skin lesions $[50,51]$. The experience of our Unit showed that Bleomycin is indicated in case of an inadequate response to Propranolol, alone or in combination with it. Reports in the literature show that Bleomycin provides better results than Triamcinolone in the treatment of $\mathrm{IH}[6,43,50,52]$.

\section{$\beta$-Blocker therapy}

$\beta$-Blocker therapy has been required since 2008, when two infants treated with Propranolol for heart disease also had spectacular remission of IH [5]. Possible administration options include systemic therapy with Propranolol or Nadolol and topical applications with Timolol [53, 54]. A non-cardioselective antagonist of $\beta_{1}$ - and $\beta_{2}$-adrenergic receptors, Propranolol appears to act by vasoconstricting high-flow blood vessels $[10,55,56]$. Nadolol has been suggested as an alternative to Propranolol because of a lower rate of complications, since Nadolol does not cross the brain barrier and does not exhibit membrane stabilizing effects $[41,45,57]$. Timolol is indicated alone [2] or in combination with laser therapy, in the case of superficial, smaller IH or in residual telangiectasias after treatment with Propranolol [41, 53, 58]. To date, Propranolol and Timolol have been maintained as first-line therapy in IH management, due to the efficacy at various locations of $\mathrm{IH}$ and the absence of significant adverse effects [3, 8, $13,14,16,59]$. Nadolol has been cited in a case report of a 10-year-old girl who, after being started on a therapy course for IH, died within seven weeks of treatment, with a postmortem concentration of Nadolol of $0.94 \mathrm{mg} / \mathrm{L}$ [60]. The infant had no bowel movements 10 days before her death. The authors of the case report suggest monitoring bowel movements in pediatric patients receiving systemic therapy with Nadolol, since this particular molecule is excreted in the feces and, in the case of discontinued bowel movements may present increased absorption [60].

Regarding Timolol, among its side effects, the literature cites transient alopecia, pulmonary fibrosis, pulmonary hypertension, hematological toxicity, hyperpigmented scars [41, 43].

Propranolol remains the main $\beta$-blocker and recent research found new ways to deliver it to the area of interest. Nanotechnology applied in the field of drug therapy helped design nanostructures that enhance drug administration efficiency. Mesoporous silica nanoparticles (MSNs) have an important role in cancer therapy and, Propranolol loading into MSNs, seem to have a cumulative effect of apoptosis of hemangioma stem cells and cell proliferation suppression [61]. The mechanism found at the base of this phenomenon is autophagy induced by synchronous release of Propranolol and nanoparticles from the MSNs and autophagosome accumulation caused by autophagy induction combined with autophagy blockade. Another mechanism consists of reactive oxygen species (ROS) generation by the Propranolol-MSNs coupling with subsequent apoptotic effects. What makes MSNs an attractive way for Propranolol delivery is the fact that this technology allows usage of lower $\beta$-blocker doses and ensures a targeted drug delivery [61].

Propranolol-loaded liposomes-in-microsphere (PLIM) is another form of prolonged delivery of Propranolol, which showed enhanced therapeutic effects when compared with free Propranolol [62].

\section{Laser therapy}

Laser therapy is an option for superficial, early detected hemangiomas or as an adjuvant therapy for refractory or ulcerated lesions $[40,58,63]$. Pulse dye laser (PDL) photocoagulates targeted vessels while leaving the overlying skin intact $[4,43,63]$.

In cases with giant hemangiomas, associated with complications, surgical treatment is the first choice for treatment $[7,64]$.

$\mathrm{IH}$ has an increased frequency among the female pediatric population, with the predominance of its localization at the skin level. The patient diagnosed with IH has the possibility of conservative treatment interventional therapy (laser therapy) or surgery. According 
to the American Academy of Pediatrics (AAP), there are five indicators that prompt therapy is mandatory [7, 41]: life-threatening complications; functional impairment; ulceration; important associated structural anomalies; risk of permanent scarring or distortion of anatomic landmarks.

To summarize the AAP Guidelines, imaging of lesions is not necessary unless the diagnosis is uncertain, there are more than five cutaneous or there is a high suspicion of anatomic anomalies. Also, in case of uncertain diagnosis, US should be the first imaging diagnostic tool used. MRI should be performed when structural abnormalities are suspected [7, 41].

The European Guidelines recommend echo-cardiography whenever large hemangiomas are identified, as this is a high risk for high-output cardiac failure. For this group of patients and for those with intrahepatic hemangiomas, thyroid hormones monitoring is important as hypothyroidism may occur. MRI angiography is useful in evaluating patients with head and/or neck hemangiomas, in order to detect further arterial anomalies [4, 41, 44].

\section{口 Pharmacological considerations regarding Propranolol therapy}

$\beta$-Blocking therapy is by far the first choice in the treatment of $\mathrm{IH}$, imposing itself by favorable clinical evolution of the tumor formation and by the lack of notable side effects, at a daily dose of $1-3 \mathrm{mg} / \mathrm{kg}$ [59]. The duration of therapy varies between 6-12 months, depending on the response. The European Guidelines suggests a lower rebound effect after a 12-months therapy course $[4,8]$.

It is important to note the fact that Propranolol is extensively metabolized by the liver, by means of cytochrome P450 enzymes, mainly CYP2D6. The gene polymorphism of CYP2D6 ( $r$ 1135840) was found to significantly impact the plasma amounts of Propranolol. Patients with the $G / G$ genotype had a better response than those with the $C / C$ genotype [65].

\section{Highlights and pitfalls}

Although no long-term effects on the central nervous system have been documented, since Propranolol is able to cross the brain barrier, other $\beta$-blockers might become a reasonable alternative to Propranolol $[8,44,55,57]$.

Second line of therapy includes oral CSs, intralesional injection of Triamcinolone, topical Timolol, depending on the morphological characteristics. Low dose CS and Propranolol could be the appropriate therapeutical plan for patients with PHACE syndrome [41]. Surgical or laser treatment is most useful for residual skin changes and may be considered to treat some IHs [40].

Considering the important changes brought by the COVID-19 pandemic, having the clinical indicators suggested by the $H I G$ may prove useful. As such, depending on the risk group in which a patient is included, one might consider telemedicine initiation of oral or topical $\beta$ blocker or, on the contrary, house visits might be required. The standard risk group is made of patients with normal birthweight, normal cardiovascular and respiratory examination within previous four weeks, no health issues in the 24-48 hour prior to scheduled telemedicine visit, IH pattern and distribution does not match PHACE or
LUMBAR syndromes, ulcerations or minimal/superficial ulceration are absent [3].

Patient and caregiver compliance are important to consider. If a patient meets the above criteria, then initiating $\beta$-blocker therapy without in-person visit may be appropriate [3].

\section{a Conclusions}

The widespread occurrence and distribution of IHs can mimic other benign or malignant disorders. The main purpose of the clinician is to obtain a complete history, appropriate imaging, and sometime pathological examination in order to make an accurate diagnosis. The treatment of $\mathrm{IH}$ is established considering the location and extent of the tumor, number of lesions and their stage and distribution, presence of systemic involvement and/or local complications. The management of IH cases should be performed in agreement with the available guidelines. The choice between systemic or topical administration, surgery and laser therapy should be made after careful prognostic evaluation and should consider the patient compliance. Newer strategies of drug delivery may prove to be an attractive alternative to invasive measures, as more studies evaluate safety profile in direct correlation with patient's characteristics.

\section{Conflict of interests}

The authors declare that they have no conflict of interests.

\section{References}

[1] Schupp CJ, Kleber JB, Günther P, Holland-Cunz S. Propranolol therapy in 55 infants with infantile hemangioma: dosage, duration, adverse effects, and outcome. Pediatr Dermatol, 2011, 28(6):640-644. https://doi.org/10.1111/j.1525-1470.2011. 01569.x PMID: 21995836

[2] Cheraghlou S, Lim Y, Choate K. Genetic investigation of childhood vascular tumor biology reveals pathways for therapeutic intervention. F1000Res, 2019, 8:F1000 Faculty Rev-590. https://doi.org/10.12688/f1000research.16160.1 PMID: 31069062 PMCID: PMC6492225

[3] Frieden IJ, Püttgen KB, Drolet BA, Garzon MC, Chamlin SL, Pope E, Mancini AJ, Lauren CT, Mathes EF, Siegel DH, Gupta D, Haggstrom AN, Tollefson MM, Baselga E, Morel KD, Shah SD, Holland KE, Adams DM, Horii KA, Newell BD, Powell J, McCuaig CC, Nopper AJ, Metry DW, Maguiness S; Hemangioma Investigator Group. Management of infantile hemangiomas during the COVID pandemic. Pediatr Dermatol, 2020, 37(3):412-418. https://doi.org/10.1111/pde.14196 PMID: 32298480 PMCID: PMC7262142

[4] Hoeger PH, Harper JI, Baselga E, Bonnet D, Boon LM, Ciofi Degli Atti M, El Hachem M, Oranje AP, Rubin AT, Weibel L, Léauté-Labrèze $C$. Treatment of infantile haemangiomas: recommendations of a European expert group. Eur J Pediatr, 2015, 174(7):855-865. https://doi.org/10.1007/s00431-0152570-0 PMID: 26021855

[5] Léauté-Labrèze C, Dumas de la Roque E, Hubiche T, Boralevi F, Thambo JB, Taïeb A. Propranolol for severe hemangiomas of infancy. N Engl J Med, 2008, 358(24):2649-2651. https:// doi.org/10.1056/NEJMc0708819 PMID: 18550886

[6] Pandey V, Tiwari P, Sharma SP, Kumar R, Singh OP. Role of intralesional bleomycin and intralesional triamcinolone therapy in residual haemangioma following propranolol. Int J Oral Maxillofac Surg, 2018, 47(7):908-912. https://doi.org/10.1016/ j.ijom.2018.03.024 PMID: 29665992

[7] Callahan $A B$, Yoon MK. Infantile hemangiomas: a review. Saudi J Ophthalmol, 2012, 26(3):283-291. https://doi.org/10. 1016/j.sjopt.2012.05.004 PMID: 23961007 PMCID: PMC 3729453

[8] Drolet BA, Frommelt PC, Chamlin SL, Haggstrom A, Bauman NM, Chiu YE, Chun RH, Garzon MC, Holland KE, Liberman L, 
MacLellan-Tobert S, Mancini AJ, Metry D, Puttgen KB, Seefeldt M, Sidbury R, Ward KM, Blei F, Baselga E, Cassidy L, Darrow DH, Joachim S, Kwon EKM, Martin K, Perkins J Siegel DH, Boucek RJ, Frieden IJ. Initiation and use of propranolol for infantile hemangioma: report of a consensus conference. Pediatrics, 2013, 131(1):128-140. https://doi.org/ 10.1542/peds.2012-1691 PMID: 23266923 PMCID: PMC 3529954

[9] Chen J, Wu D, Dong Z, Chen A, Liu S. The expression and role of glycolysis-associated molecules in infantile hemangioma. Life Sci, 2020, 259:118215. https://doi.org/10.1016/ j.lfs.2020.118215 PMID: 32768579

[10] Awadein A, Fakhry MA. Evaluation of intralesional propranolol for periocular capillary hemangioma. Clin Ophthalmol, 2011, 5:1135-1140. https://doi.org/10.2147/OPTH.S22909 PMID: 21887095 PMCID: PMC3162293

[11] Luo W, Hu H, Chang R, Zhong J, Knabel M, O'Meally R, Cole RN, Pandey A, Semenza GL. Pyruvate kinase M2 is a PHD3stimulated coactivator for hypoxia-inducible factor 1. Cell, 2011, 145(5):732-744. https://doi.org/10.1016/j.cell.2011. 03.054 PMID: 21620138 PMCID: PMC3130564

[12] Draoui N, de Zeeuw P, Carmeliet P. Angiogenesis revisited from a metabolic perspective: role and therapeutic implications of endothelial cell metabolism. Open Biol, 2017, 7(12):170219. https://doi.org/10.1098/rsob.170219 PMID: 29263247 PMCID: PMC5746547

[13] Gupta A, Kozakewich H. Histopathology of vascular anomalies. Clin Plast Surg, 2011, 38(1):31-44. https://doi.org/10.1016/ j.cps.2010.08.007 PMID: 21095470

[14] Tarcă E, Cojocaru E, Roşu ST, Butnariu LI, Plămădeală $P$, Moisă ŞM. Differential diagnosis difficulties related to infantile hemangioma - case report and literature review. Rom J Morphol Embryol, 2019, 60(4):1375-1379. PMID: 32239121

[15] Osaki TH, Jakobiec FA, Mendoza PR, Lee Y, Fay AM. Immunohistochemical investigations of orbital infantile hemangiomas and adult encapsulated cavernous venous lesions (malformation versus hemangioma). Ophthalmic Plast Reconstr Surg, 2013 29(3):183-195. https://doi.org/10.1097/IOP.0b013e31828b0f1f PMID: 23584448

[16] Greenberger S, Bischoff J. Pathogenesis of infantile haemangioma. Br J Dermatol, 2013, 169(1):12-19. https://doi.org/ 10.1111/bjd.12435 PMID: 23668474 PMCID: PMC3707963

[17] Castrén E, Salminen P, Vikkula M, Pitkäranta A, Klockars T. Inheritance patterns of infantile hemangioma. Pediatrics, 2016, 138(5):e20161623. https://doi.org/10.1542/peds.20161623

[18] Gomez-Acevedo H, Dai Y, Strub G, Shawber C, Wu JK Richter GT. Identification of putative biomarkers for infantile hemangiomas and propranolol treatment via data integration Sci Rep, 2020, 10(1):3261. https://doi.org/10.1038/s41598020-60025-2 PMID: 32094357 PMCID: PMC7039967

[19] Vohra V, Gupta P, Malik PK, Pathak A. Propranolol therapy in a case of capillary hemangioma. Oman J Ophthalmol, 2015, 8(3):191-193. https://doi.org/10.4103/0974-620X.169907 PMID: 26903730 PMCID: PMC4738669

[20] Bahramsoltani M, Slosarek I, De Spiegelaere W, Plendl J. Angiogenesis and collagen type IV expression in different endothelial cell culture systems. Anat Histol Embryol, 2014 43(2):103-115. https://doi.org/10.1111/ahe.12052 PMID: 23551189

[21] Barwe SP, Jordan MC, Skay A, Inge L, Rajasekaran SA, Wolle D, Johnson CL, Neco P, Fang K, Rozengurt N, Goldhaber JI, Roos KP, Rajasekaran AK. Dysfunction of ouabain-induced cardiac contractility in mice with heart-specific ablation of Na,K-ATPase beta1-subunit. J Mol Cell Cardiol, 2009, 47(4):552-560. https://doi.org/10.1016/j.yjmcc.2009.07.018 PMID: 19683723 PMCID: PMC2749246

[22] Arya AD, Wilson DI, Baralle D, Raponi M. RBFOX2 protein domains and cellular activities. Biochem Soc Trans, 2014, 42(4):1180-1183. https://doi.org/10.1042/BST20140050 PMID: 25110022

[23] Biswas A, Pan X, Meyer M, Khanna S, Roy S, Pearson G, Kirschner R, Witman P, Faith EF, Sen CK, Gordillo GM. Urinary excretion of microRNA-126 is a biomarker for hemangioma proliferation. Plast Reconstr Surg, 2017, 139(6): 1277e-1284e. https://doi.org/10.1097/PRS.0000000000003 349 PMID: 28538565 PMCID: PMC5963954

[24] Schultz BE, Spock CR, Tom LK, Kong Y, Canadas KT, Kim S, Waner M, O T, Antaya R, Narayan D. MicroRNA microarray profiling in infantile hemangiomas. Eplasty, 2019, 19:e13. PMID: 31068993 PMCID: PMC6482871

[25] Strub GM, Kirsh AL, Whipple ME, Kuo WP, Keller RB, Kapur RP, Majesky MW, Perkins JA. Endothelial and circulating C19MC microRNAs are biomarkers of infantile hemangioma. $\mathrm{JCl}$ Insight, 2016, 1:e88856. https://doi.org/10.1172/jci.insight.8 8856 PMID: 27660822 PMCID: PMC5029419

[26] Sethuraman G, Yenamandra VK, Gupta V. Management of infantile hemangiomas: current trends. J Cutan Aesthet Surg, 2014, 7(2):75-85. https://doi.org/10.4103/0974-2077.138324 PMID: 25136206 PMCID: PMC4134656

[27] Cantisani V, Del Vecchio A, Fioravanti E, Romeo U, D'Ambrosio F. Color-Doppler US features of a pyogenic granuloma of the upper dorsum tongue. J Ultrasound, 2014, 19(1):67-70. https:// doi.org/10.1007/s40477-014-0121-6 PMID: 26941877 PMCID: PMC4762846

[28] Hayashi Y, Hosoe N, Takabayashi K, Kamiya KJL, Mutaguchi M, Miyanaga R, Hirata K, Fukuhara S, Mikami $Y$, Sujino $T$, Masugi $Y$, Naganuma M, Ogata $H$, Kanai T. Clinical and endoscopic characteristics of pyogenic granuloma in the small intestine: a case series with literature review. Intern Med, 2020, 59(4):501-505. https://doi.org/10.2169/internalmedicine. 3745-19 PMID: 31611535 PMCID: PMC7056362

[29] Zaltsberg GS, Spring S, Malic C, Koujok K, Davila J, Hurteau J, Shenouda N. Soft tissue lesions with high vascular density on sonography in pediatric patients: beyond hemangiomas. Can Assoc Radiol J, 2020, 71(4):505-513. https://doi.org/10. 1177/0846537119899539 PMID: 32054306

[30] Parekh V, Guerrero CE, Knapp CF, Elmets CA, McKay KM. A histological snapshot of hypothetical multistep progression from nevus sebaceus to invasive syringocystadenocarcinoma papilliferum. Am J Dermatopathol, 2016, 38(1):56-62. https:// doi.org/10.1097/DAD.0000000000000370 PMID: 26317389

[31] Shin JW, Park HS, Kim BK, Kim YA, Kim MG, Won CH, Cho S. Aneurysmal benign fibrous histiocytoma with atrophic features. Ann Dermatol, 2009, 21(1):42-45. https://doi.org/10.5021/ ad.2009.21.1.42 PMID: 20548854 PMCID: PMC2883367

[32] Calonje E, Fletcher CD. Aneurysmal benign fibrous histiocytoma: clinicopathological analysis of 40 cases of a tumour frequently misdiagnosed as a vascular neoplasm. Histopathology, 1995, 26(4):323-331. https://doi.org/10.1111/j.1365-2559.1995.tb00 193.x PMID: 7607620

[33] Flevas DA, Syngouna S, Fandridis E, Tsiodras S, Mavrogenis AF. Infections of the hand: an overview. EFORT Open Rev, 2019, 4(5):183-193. https://doi.org/10.1302/2058-5241.4.180082 PMID: 31191986 PMCID: PMC6540949

[34] Stone OJ, Mullins JF. Chronic paronychia: microbiology and histopathology. Arch Dermatol, 1962, 86(3):324-327. https:// doi.org/10.1001/archderm.1962.01590090066015 PMID: 13917473

[35] Zavras N, Poddighe D. Cranial fasciitis of childhood (CFC): an unusual clinical case of a rare disease. BMJ Case Rep, 2017, 2017:bcr2017220859. https://doi.org/10.1136/bcr-2017220859 PMID: 28903973 PMCID: PMC5623234

[36] Munchar MJJ, Sharifah NA, Jamal R, Looi LM. CD44s expression correlated with the International Neuroblastoma Pathology Classification (Shimada system) for neuroblastic tumours. Pathology, 2003, 35(2):125-129. https://doi.org/10. 1080/0031302031000082214 PMID: 12745459

[37] Xie CF, Liu MZ, Xi M. Extraskeletal Ewing's sarcoma: a report of 18 cases and literature review. Chin J Cancer, 2010, 29(4): 420-424. https://doi.org/10.5732/cjc.009.10402 PMID: 20346219

[38] Goh GH, Petersson F. Plexiform fibrohistiocytic tumor presenting as a central neck mass clinically mimicking a thyroglossal duct cyst: an unusual case reported with histo-cytopathologic correlation and a review of the cytopathology literature. Head Neck Pathol, 2020, 14(1):262-267. https://doi.org/10.1007/ s12105-019-01022-4 PMID: 30758757 PMCID: PMC7021857

[39] Donnelly LF, Adams DM, Bisset GS 3rd. Vascular malformations and hemangiomas: a practical approach in a multidisciplinary clinic. AJR Am J Roentgenol, 2000, 174(3):597608. https://doi.org/10.2214/ajr.174.3.1740597 PMID: 10701595

[40] Zheng JW, Zhang L, Zhou Q, Mai HM, Wang YA, Fan XD, Qin ZP, Wang XK, Zhao YF. A practical guide to treatment of infantile hemangiomas of the head and neck. Int J Clin Exp Med, 2013, 6(10):851-860. PMID: 24260591 PMCID: PMC3832322

[41] Krowchuk DP, Frieden IJ, Mancini AJ, Darrow DH, Blei F, Greene AK, Annam A, Baker CN, Frommelt PC, Hodak A, 
Pate BM, Pelletier JL, Sandrock D, Weinberg ST, Whelan MA; Subcommittee on the Management of Infantile Hemangiomas. Clinical practice guideline for the management of infantile hemangiomas. Pediatrics, 2019, 143(1):e20183475. https:// doi.org/10.1542/peds.2018-3475 PMID: 30584062

[42] Cheng CE, Friedlander SF. Infantile hemangiomas, complications and treatments. Semin Cutan Med Surg, 2016, 35(3): 108-116. https://doi.org/10.12788/j.sder.2016.050 PMID: 27607318

[43] Satterfield KR, Chambers CB. Current treatment and management of infantile hemangiomas. Surv Ophthalmol, 2019, 64(5):608-618. https://doi.org/10.1016/j.survophthal.2019.02. 005 PMID: 30772366

[44] Greenberger S, Bischoff J. Infantile hemangioma - mechanism(s) of drug action on a vascular tumor. Cold Spring Harb Perspect Med, 2011, 1(1):a006460. https://doi.org/10.1101/cshperspect. a006460 PMID: 22229118 PMCID: PMC3234458

[45] Kim KH, Choi TH, Choi Y, Park YW, Hong KY, Kim DY, Choe YS, Lee H, Cheon JE, Park JB, Park KD, Kang HJ, Shin HY, Jeong $\mathrm{JH}$. Comparison of efficacy and safety between propranolol and steroid for infantile hemangioma: a randomized clinical trial. JAMA Dermatol, 2017, 153(6):529536. https://doi.org/10.1001/jamadermatol.2017.0250 PMID: 28423174 PMCID: PMC5817616

[46] Senchak AJ, Dann M, Cable B, Bessinger G. Successful treatment of cutaneous hemangioma of infancy with topical imiquimod 5\%: a report of 3 cases. Ear Nose Throat J, 2010, 89(3):E21-E25. PMID: 20229466

[47] Wu HW, Wang X, Zhang L, Zhao HG, Wang YA, Su LX, Fan $X D$, Zheng JW. Interferon-alpha therapy for refractory kaposiform hemangioendothelioma: a single-center experience. Sci Rep, 2016, 6:36261. https://doi.org/10.1038/srep36261 PMID: 27796340 PMCID: PMC5087085

[48] Zaher H, Rasheed H, El-Komy MM, Hegazy RA, Gawdat HI, Abdel Halim DM, Abdel Hay RM, Hegazy RA, Mohy AM. Propranolol versus captopril in the treatment of infantile hemangioma $(\mathrm{IH})$ : a randomized controlled trial. J Am Acad Dermatol, 2016, 74(3):499-505. https://doi.org/10.1016/j.jaad. 2015.09.061 PMID: 26685718

[49] Fernandez-Pineda I, Lopez-Gutierrez JC, Chocarro G, Bernabeu-Wittel J, Ramirez-Villar GL. Long-term outcome of vincristine-aspirin-ticlopidine (VAT) therapy for vascular tumors associated with Kasabach-Merritt phenomenon. Pediatr Blood Cancer, 2013, 60(9):1478-1481. https://doi.org/10.1002/ pbc.24543 PMID: 23609996

[50] Luo QF, Zhao FY. The effects of Bleomycin A5 on infantile maxillofacial haemangioma. Head Face Med, 2011, 7:11 https://doi.org/10.1186/1746-160X-7-11 PMID: 21736714 PMCID: PMC3148961

[51] Muir T, Kirsten M, Fourie P, Dippenaar N, lonescu GO. Intralesional bleomycin injection (IBI) treatment for haemangiomas and congenital vascular malformations. Pediatr Surg Int, 2004, 19(12):766-773. https://doi.org/10.1007/s00383-003-1058-6 PMID: 14740248

[52] Pienaar C, Graham R, Geldenhuys S, Hudson DA. Intralesional bleomycin for the treatment of hemangiomas. Plast Reconstr Surg, 2006, 117(1):221-226. https://doi.org/10.1097/ 01.prs.0000194906.61805.b0 PMID: 16404271

[53] Chambers CB, Katowitz WR, Katowitz JA, Binenbaum G. A controlled study of topical $0.25 \%$ timolol maleate gel for the treatment of cutaneous infantile capillary hemangiomas. Ophthalmic Plast Reconstr Surg, 2012, 28(2):103-106. https:// doi.org/10.1097/IOP.0b013e31823bfffb PMID: 22410658
[54] Lubahn JG, Lee RK, Karp CL. Resolution of conjunctival sessile hemangioma with topical timolol. Cornea, 2014, 33(1): 99-100. https://doi.org/10.1097//CO.0000000000000022 PMID: 24270678 PMCID: PMC3895456

[55] Lou Y, Peng WJ, Cao Y, Cao DS, Xie J, Li HH. The effectiveness of propranolol in treating infantile haemangiomas: a meta-analysis including 35 studies. $\mathrm{Br} \mathrm{J}$ Clin Pharmacol, 2014, 78(1):44-57. https://doi.org/10.1111/bcp.12235 PMID: 24033819 PMCID: PMC4168379

[56] Sans V, de la Roque ED, Berge J, Grenier N, Boralevi F, Mazereeuw-Hautier J, Lipsker D, Dupuis E, Ezzedine K, Vergnes $\mathrm{P}$, Taïeb $\mathrm{A}$, Léauté-Labrèze $\mathrm{C}$. Propranolol for severe infantile hemangiomas: follow-up report. Pediatrics, 2009, 124(3):e423-e431. https://doi.org/10.1542/peds.2008-3458 PMID: 19706583

[57] Thai T, Wang CY, Chang CY, Brown JD. Central nervous system effects of oral propranolol for infantile hemangioma: a systematic review and meta-analysis. J Clin Med, 2019, 8(2):268. https://doi.org/10.3390/jcm8020268 PMID: 30813242 PMCID: PMC6406625

[58] Asilian A, Mokhtari F, Kamali AS, Abtahi-Naeini B, Nilforoushzadeh MA, Mostafaie S. Pulsed dye laser and topical timolol gel versus pulse dye laser in treatment of infantile hemangioma: a double-blind randomized controlled trial. Adv Biomed Res, 2015, 4:257. https://doi.org/10.4103/2277-9175.170682 PMID: 26918239 PMCID: PMC4746935

[59] Tarcă E, Gavrilescu S, Ciomagă IM, Crişcov I, Roşu TS, Savu B. Hemangiomul infantil - posibilităţi de abordare terapeutică [Infantile hemangioma - therapeutic approaching possibilities]. Pediatru.ro, 2018, XIV:50(2). https://doi.org/10. 26416/Pedi.50.2.2018.1769

[60] McGillis E, Baumann T, LeRoy J. Death associated with nadolol for infantile hemangioma: a case for improving safety. Pediatrics, 2020, 145(1):e20191035. https://doi.org/10.1542/peds.20191035 PMID: 31852735

[61] Wu H, Wang X, Liang H, Zheng J, Huang S, Zhang D. Enhanced efficacy of propranolol therapy for infantile hemangiomas based on a mesoporous silica nanoplatform through mediating autophagy dysfunction. Acta Biomater, 2020, 107:272-285. https://doi.org/10.1016/j.actbio.2020.02.033 PMID: 32145394

[62] Guo X, Zhu X, Liu D, Gong Y, Sun J, Dong C. Continuous delivery of propranolol from liposomes-in-microspheres significantly inhibits infantile hemangioma growth. Int J Nanomedicine, 2017, 12:6923-6936. https://doi.org/10.2147/ IJN.S137634 PMID: 29075111 PMCID: PMC5609781

[63] Kwon SH, Choi JW, Byun SY, Kim BR, Park KC, Youn SW, Huh $\mathrm{CH}, \mathrm{Na} \mathrm{JI}$. Effect of early long-pulse pulsed dye laser treatment in infantile hemangiomas. Dermatol Surg, 2014, 40(4):405-411. https://doi.org/10.1111/dsu.12451 PMID: 24460784

[64] Adhikary B, Sen S, Banerjee P, Bandyopadhyay S, Mukherjee D, Bandyopadhyay S, Kumar P, Majumder A. Haemangioma of cheek different presentation and management. Indian J Otolaryngol Head Neck Surg, 2014, 66(2):162-166. https:// doi.org/10.1007/s12070-013-0697-8 PMID: 24822155 PMCID: PMC4016354

[65] Wang L, Zheng K, Li X, Wang Y, Xu Q. Influence of cytochrome P450 2D6 polymorphisms on the efficacy of oral propranolol in treating infantile hemangioma. Biomed Res Int, 2020, 2020:8732871. https://doi.org/10.1155/2020/8732871 PMID: 32219146 PMCID: PMC7081015

\section{Corresponding authors}

Elena Cojocaru, Associate Professor, MD, PhD, Department of Morphofunctional Sciences I - Pathology, Grigore T. Popa University of Medicine and Pharmacy, 16 University Street, 700115 laşi, Romania; Phone +40745367 144, e-mail: ellacojocaru@yahoo.com

Laura Mihaela Trandafir, Associate Professor, MD, PhD, Department of Mother and Child Medicine - Pediatrics, Grigore T. Popa University of Medicine and Pharmacy, 16 University Street, 700115 laşi, Romania; Phone +40721471 041, e-mail: trandafirlaura@yahoo.com 